\title{
Urinary Enzymes and Microalbuminuria as Indicators of Renal Nephropathy in Saudi Patients
}

\author{
Sahirah A. Lary \\ Department of Biochemistry, Faculty of Science, \\ King Abdulaziz University, Jeddah, Saudi Arabia
}

Abstract. In the current work we tried to investigate some new biochemical markers in the urine of kidney patients, kidney transplant recipients and control subjects of the Saudi population, such markers are $\mathrm{N}$-acetyl- $\beta$-D-glucosaminidase (NAG), Alkaline Phosphatase (ALP), Alanine Aminopeptidase (AAP) as well as microalbuminuria. Kidney patients, males and females, age ranged from 16-85 years, and kidney transplant recipients, male and female, age ranged from 18-75 years.

Results from control subjects showed a slight elevation of total urinary protein and NAG in females. This may be due to the higher level of creatinine concentration in male subjects, that would result in lower protein concentration and NAG activity when expressed in terms of creatinine. Microalbuminuria, glucose and $\mathrm{pH}$ results were in close agreement with the published data and no sex differences were recorded when compared with the males. There were statistically significant differences in most of parameters investigated between kidney patients and the normal population except for glucose level and $\mathrm{pH}$ value. The reduction in creatinine concentration may reflect changes in the glomerular filtration rate (GRF). Higher levels of urinary NAG activity were associated with high microalbuminuria and raised AAP levels.

Increase urinary NAG predominantly reflects decreased renal function and tubular damage. ALP increased levels reflect a lesion of the proximal convoluted tubules and/or intensive degeneration of the tubular epithelial cells. The increase in NAG activity correlates well with urinary protein and may indicate an increase in activity of renal tubular cells. Kidney transplant recipients showed a significant increase in NAG, ALP and AAP enzymes compared to control subjects. The marked increase in most parameters may indicate that patients are in an immediate functioning graft. 


\section{Introduction}

The kidney is subjected to toxins because of its high blood supply and metabolic activity ${ }^{[1]}$. Renal damage is often occurs basically in specific regions of the nephron ${ }^{[2]}$ and in most instance are irreversible ${ }^{[3]}$. Variety of procedures have been used to diagnose renal damage and the final diagnosis however is dependent on morphological evidence such as biopsy material which is carried out when the disease is well established ${ }^{[1]}$. Most commonly used renal function tests are insensitive and fail to identify early lesions, in addition biopsy sampling is not recommended in most cases except in the presence of well established renal disease ${ }^{[3]}$. The side effects of these procedure used such as the effect of X-ray and biopsy have urged the investigators to search a non-invasive procedure which can be used as an early and sensitive indicator for kidney damage and for a continuous monitoring of kidney patients.

The value of urinary enzyme assay in the detection and assessment of a number of renal disorders is now well established. Therefore, the evaluation of enzymuria originating in renal tubules is a valuable tool in the diagnosis of impaired renal function ${ }^{[2]}$.

The assessment of lysosomal NAG in urine can be used as a sensitive indicator for toxic renal damage and was used extensively to monitor renal disease ${ }^{[4]}$. Increased urinary NAG predominantly reflects glomerular levels ${ }^{[5]} \mathrm{NAG}$, also may provide a useful indicator of renal involvement in hypertension, early warning of rejection crisis ${ }^{[6,1]}$. On the other hand, the brush boarder enzymes of the proximal tubule involved in the amino acid metabolism such as alanine aminopeptidase (AAP) reflects decreased renal function and tubular damage ${ }^{[7]}$.

Proteinuria could also be an indication of glomerular or tubular disease, as well as microalbuminuria a raised excretion of albumin above the reference range $(<200 \mathrm{mg} / \mathrm{L})$ for healthy non-diabetic subjects and is undetectable by albustic test ${ }^{[8,9]}$. Microalbuminuria however is of glomerular origin and is associated with normal tubular function ${ }^{[10,11]}$.

The objective of this work is to use N-acetyl- $\beta$-D-glucosaminidase (NAG), alkaline phosphatase (ALP), alanine aminopeptidase (AAP) as early, noninvasive and sensitive indicators for renal damage in kidney patients and to detect the function of the kidney in renal transplant patients.

\section{Materials and Methods}

\section{Control Subject}

One hundred and fifty-five normal subjects without clinical evidence of renal disease, hypertension or diabetes mellitus were studied. None of these controls 
were under medication or smokers. Their body index were, males $=23.60 \pm 40$ $\mathrm{kg} / \mathrm{m}^{2}$ and female $=22.27 \pm 3.72 \mathrm{~kg} / \mathrm{m}^{2}$. These age-matched subjects comprised students and staff member volunteers from King Abdulaziz University Hospital, King Fahad General Hospital and others who were visiting the hospitals for a routine check-up.

\section{Kidney Patients}

Kidney patients consisted of two groups, kidney patients with different nephropathy and kidney transplant recipients. Kidney patient group with different nephropathy consisted of 57 patients, 27 males and 30 females. The mean age of the group was $43.6 \pm 17$ years. Patients were at diagnosis when urine sample was collected. Classification of patient was based on clinical examination and laboratory findings. Kidney transplant recipients consisted of 50 patients, 40 males and 10 females. Patients were at diagnosis when urine sample was collected. Classification of patients was also based on clinical examination and laboratory findings. Transplants were 6-18 months post surgery when urine samples was collected.

Both control subjects and patients provided a mid day urine sample. Control subjects provided a brief medical history which included personal details. Data obtained for each individual included body mass index, temperature, blood pressure and heart beat rate. Clinical data on the patients was determined from their case histories.

Samples: $(5 \mathrm{ml})$ were aliquoted and stored until required at $-20^{\circ} \mathrm{C}$ without preservation. Samples $(3 \mathrm{ml})$ were also aliquoted and stored in $30 \%$ glycerol for the assay of alanine aminopeptidase (AAP). Some assays were carried out immediately prior to freezing the urine.

\section{Analytical Method}

Urinary NAG activity as $\mu \mathrm{mol} / \mathrm{MNP}$ released/h/L (MNP-GcNAc-2-methoxy4-(2 nitrovinly) phenyl-2-acetamido-2-deoxy- $\beta$-D-glycopyranoside) was assayed without freezing ${ }^{[6]}$ using a NAG kit (PPR Diagnostic Ltd, UK). Absorbance at $505 \mathrm{~nm}$ was measured using a Pharmacia Novaspec II spectrophotometer. Urinary creatinine concentration $(\mathrm{mmol} / \mathrm{K})$ was determined using the Bonsens and Taussky method ${ }^{[12]}$ based on the Jaffe reaction ${ }^{[13]}$. The determination of creatinine was carried out in order to correct for variations caused by change in urine flow ${ }^{[14]}$. AAP activity $(\mathrm{u} / \mathrm{mol} \mathrm{Cr})$ was carried out according to the method of Mattenheimer et al. ${ }^{[15]}$. Total protein $(\mathrm{mg} / \mathrm{mmol} \mathrm{Cr})$ was assayed according to the method of Bradford ${ }^{[16]}$ using Coomassie Briliant Blue G-250 and BSA (BDH Chemicals Ltd. Poole, England). Microalbuminuria (mmol/L) was basi- 
cally detected by the Micral-test strips (Boehringer). This test allows specific detection of human albumin $(<200 \mathrm{mg} / \mathrm{L})$ and the intensity of the dye after exactly $5 \mathrm{~min}$ is directly proportional to the albumin content of the urine. A more reliable test, Elisa a double antibody sandwich technique (Price Lab, King's College, London) was also used for the detection of microalbuminuria. Urine, $\mathrm{pH}$, glucose $(\mathrm{mg} / \mathrm{dl})$ and albumin $(\mathrm{mg} / \mathrm{L})$ were detected using ComburTest strips (Boehringer).

\section{Results}

\section{Normal Subjects}

Urine samples from healthy Saudi subjects without any history of renal disease, hypertension or diabetes mellitus were free of glucose, had normal $\mathrm{pH}$ values and $\mathrm{NAG}^{[17]}, \mathrm{AAP}^{[18]}$, microalbuminuria ${ }^{[19]}$ and total protein values (Table 1). No significant differences were found between males and females, data was then pooled for the whole group.

Table 1. Percentile for normal Saudi males and females at $2.5 \%$ and $97.5 \%$. The means, standard deviations, upper and lower limits and reference intervals. Males $(n=$ 59), $\mathrm{Cr}=$ creatinine.

\begin{tabular}{|c|c|c|c|c|c|c|c|c|}
\hline \multirow[b]{2}{*}{ Parameters } & \multicolumn{3}{|c|}{ Males } & \multicolumn{3}{|c|}{ Females } & \multirow[b]{2}{*}{$\begin{array}{l}\text { Reference } \\
\text { range for } \\
\text { normal } \\
\text { Saudi } \\
\text { males and } \\
\text { females }\end{array}$} & \multirow[b]{2}{*}{$\begin{array}{c}\text { Normal } \\
\text { males \& } \\
\text { females }\end{array}$} \\
\hline & $\begin{array}{c}\text { Mean } \pm \text { SD } \\
14.14 \pm 0.7\end{array}$ & $\begin{array}{c}\text { Lower } \\
\text { limit } \\
\text { of } \\
\text { normal } \\
2.5 \%\end{array}$ & $\begin{array}{c}\text { Upper } \\
\text { limit } \\
\text { of } \\
\text { normal } \\
97.5 \%\end{array}$ & Mean \pm SD & \begin{tabular}{|c} 
Lower \\
limit \\
of \\
normal \\
$2.5 \%$
\end{tabular} & \begin{tabular}{|c} 
Upper \\
limit \\
of \\
normal \\
$97.5 \%$
\end{tabular} & & \\
\hline $\begin{array}{l}\text { Creatinine } \\
(\mathrm{mmol})\end{array}$ & $14.14 \pm 0.7$ & 3.0 & 26.5 & $13.46 \pm 0.6$ & 3.23 & 29.59 & $2.2-31$ & $13.7 \pm 0.5$ \\
\hline $\begin{array}{l}\text { NAG } \\
(\mu \mathrm{mol} / \mathrm{h} \mathrm{mol} \mathrm{Cr})\end{array}$ & $10.75 \pm 0.9$ & 2.0 & 31.5 & $13.52 \pm 0.76$ & 2.84 & 36.94 & $3-45$ & $12.5 \pm 0.6$ \\
\hline $\begin{array}{l}\text { AAP } \\
(\mathrm{U} / \mathrm{mmol} \mathrm{Cr})\end{array}$ & $1.18 \pm 0.4$ & 0.0 & 2.01 & $1.3 \pm 0.65$ & 0.0 & 2.24 & $0.41-2.3$ & $1.3 \pm 0.6$ \\
\hline $\begin{array}{l}\text { ALP } \\
(\mathrm{U} / \mathrm{mmol} \mathrm{Cr})\end{array}$ & $0.24 \pm 0.2$ & - & - & - & - & - & - & $0.34 \pm 0.2$ \\
\hline $\begin{array}{l}\text { Total protein } \\
(\mathrm{mg} / \mathrm{mmol} \mathrm{Cr})\end{array}$ & $6.41 \pm 0.5$ & 2.25 & 21.35 & $7.39 \pm 0.51$ & 2.4 & 24.09 & $1.3-42$ & $7.0 \pm 0.4$ \\
\hline $\begin{array}{l}\text { Microalbuminu- } \\
\text { ria }(\mathrm{mg} / \mathrm{mmol} \\
\mathrm{Cr})\end{array}$ & $0.91 \pm 1.9$ & 0.0 & 0.9 & $0.9 \pm 2$ & 0.0 & 0.9 & $0-6$ & $0.86 \pm 1.8$ \\
\hline Glucose (mg/dl) & $<50$ & - & - & $<50$ & - & - & - & $<50$ \\
\hline $\mathrm{pH}$ & $5.24 \pm 0.09$ & - & - & $5.25 \pm 0.07$ & - & - & - & $5.25 \pm 0.07$ \\
\hline
\end{tabular}




\section{Kidney Patients and Kidney Transplant Recipients}

Dipstick tests were used to investigate urine albumin, glucose and $\mathrm{pH}$. For kidney damage patients (Table 2) a rough estimation of albumin was carried out for the patients using Albustix (Table 2), followed by the test for microalbuminuria (Elisa technique). It was also necessary to look for more reliable and sensitive markers such as NAG, AAP, ALP and total protein. Creatinine was determined and used as a reference to correct the concentration of the parameters.

Table 2. Comparison between male and female kidney patients. The means and standard deviations of the studied parameters for kidney patients $(n=57)$, males $(n=27)$ and females $(\mathrm{n}=\mathbf{3 0}), \mathrm{Cr}=$ creatinine.

\begin{tabular}{|l|c|c|c|c|}
\hline \multirow{2}{*}{ Parameters } & Males & Females & \multirow{2}{*}{ P - value } & Males \& females \\
\cline { 2 - 3 } & Mean \pm SD & Mean \pm SD & & Mean \pm SD \\
\hline Creatinine $(\mathrm{mmol} / \mathrm{l})$ & $8.8 \pm 5.5$ & $8.0 \pm 4.3$ & NS & $8.4 \pm 4.9$ \\
\hline $\begin{array}{c}\text { NAG }(\mu \mathrm{mol} / \mathrm{h} / \mathrm{mmol} \\
\text { creatinine) }\end{array}$ & $75.3 \pm 67$ & $88.9 \pm 69.0$ & 0.25 & $41.7 \pm 67.8$ \\
\hline AAP $(\mathrm{U} / \mathrm{mmol}$ creatinine) & $3.7 \pm 0.84$ & $3.2 \pm 0.44$ & NS & $3.5 \pm 0.6$ \\
\hline ALP $(\mathrm{U} / \mathrm{mmol}$ creatinine) & $1.37 \pm 0.71$ & $1.57 \pm 1.07$ & 0.4 & $1.37 \pm 0.89$ \\
\hline $\begin{array}{c}\text { Total protein }(\mathrm{mg} / \mathrm{mmol} \\
\text { creatinine) }\end{array}$ & $111.4 \pm 93.7$ & $132.9 \pm 72.31$ & 0.15 & $122.20 \pm 83$ \\
\hline $\begin{array}{l}\text { Microalbuminuria } \\
(\mathrm{mg} / \mathrm{mmol} \mathrm{creatinine})\end{array}$ & $19.04 \pm 43.0$ & $12.42 \pm 7.74$ & 0.20 & $15.73 \pm 5.8$ \\
\hline Glucose $(\mathrm{mg} / \mathrm{dl})$ & $<50$ & $<50$ & - & - \\
\hline pH & $5.7 \pm 1.3$ & $5.2 \pm 0.5$ & NS & $5.5 \pm 0.9$ \\
\hline
\end{tabular}

The results obtained are represented as mean \pm SD of the parameters which show no statistical difference as calculated for the parameters in both groups, although there are some differences in total protein and microalbuminuria.

A comparison between kidney normal controls and kidney damage patients is shown in Table 3. There were significant differences in all parameters investigated except in glucose level and $\mathrm{pH}$ value; in both groups blood glucose was $<50 \mathrm{mg} / \mathrm{dl}$ and $\mathrm{pH}(\mathrm{p}=0.46)$.

\section{Kidney Transplant Recipients}

The results obtained from the recipients are presented in Table 4 .

A comparison between male and female kidney patients is also shown in this table. No statistical difference was observed between the two groups, although there are differences in NAG activity. 
Table 3. Comparison between control subjects and kidney patients. The means and standard deviations of the studied parameters for normal control $(n=155)$, and kidney patients $(\mathrm{n}=\mathbf{5 7}), \mathrm{Cr}=$ creatinine.

\begin{tabular}{|l|c|c|c|}
\hline \multirow{2}{*}{ Parameters } & Control subjects & Kidney patients & \multirow{2}{*}{ P - value } \\
\cline { 2 - 4 } & Mean \pm SD & Mean \pm SD & \\
\hline Creatinine $(\mathrm{mmol} / \mathrm{l})$ & $13.7 \pm 0.5$ & $8.4 \pm 4.9$ & 0.001 \\
\hline NAG $(\mu \mathrm{mol} / \mathrm{h} / \mathrm{mmol}$ creatinine) & $12.46 \pm 0.6$ & $41.7 \pm 67.8$ & 0.001 \\
\hline AAP $(\mathrm{U} / \mathrm{mmol}$ creatinine) & $1.3 \pm 0.58$ & $3.6 \pm 0.6$ & 0.001 \\
\hline ALP $(\mathrm{U} / \mathrm{mmol}$ creatinine) & $0.34 \pm 0.2$ & $1.47 \pm 0.89$ & $<0.001$ \\
\hline Total protein (mg/mmol creatinine) & $7.01 \pm 0.37$ & $122.2 \pm 8.3$ & 0.001 \\
\hline Microalbuminuria (mg/mmol creatinine) & $0.9 \pm 1.8$ & $15.73 \pm 58$ & 0.001 \\
\hline Glucose (mg/dl) & $<50$ & $<50$ & - \\
\hline pH & $5.25 \pm 0.007$ & $5.5 \pm 0.9$ & - \\
\hline
\end{tabular}

Table 4. Comparison between male and female kidney patients. The means and standard deviations of the studied parameters for kidney transplant patients $(n=57)$, male $(\mathrm{n}=27)$ and females $(\mathrm{n}=\mathbf{3 0}), \mathrm{Cr}=$ creatinine.

\begin{tabular}{|c|c|c|c|c|}
\hline \multirow{2}{*}{ Parameters } & Males & Females & \multirow{2}{*}{$P$ - value } & Males \& females \\
\hline & Mean \pm SD & Mean \pm SD & & Mean \pm SD \\
\hline Creatinine $(\mathrm{mmol} / \mathrm{l})$ & $11.31 \pm 6.4$ & $9.86 \pm 4.97$ & Ns & $10.84 \pm 6.11$ \\
\hline $\begin{array}{l}\mathrm{NAG}(\mu \mathrm{mol} / \mathrm{h} / \mathrm{mmol} \\
\text { creatinine })\end{array}$ & $75.62 \pm 81.3$ & $95.27 \pm 66.8$ & Ns & $85.44 \pm 74.0$ \\
\hline AAP $(\mathrm{U} / \mathrm{mmol}$ creatinine $)$ & $2.52 \pm 2.9$ & $2.20 \pm 1$ & Ns & $2.46 \pm 2.72$ \\
\hline $\operatorname{ALP}(\mathrm{U} / \mathrm{mmol}$ creatinine $)$ & $0.85 \pm 0.88$ & $0.74 \pm 0.43$ & Ns & - \\
\hline $\begin{array}{l}\text { Total protein }(\mathrm{mg} / \mathrm{mmol} \\
\text { creatinine) }\end{array}$ & $79.03 \pm 184.3$ & $76.59 \pm 103.10$ & Ns & $77.81 \pm 147.72$ \\
\hline $\begin{array}{l}\text { Microalbuminuria } \\
\text { (mg/mmol creatinine) }\end{array}$ & $5.87 \pm 10.9$ & $4.20 \pm 5.80$ & Ns & $5.04 \pm 9$ \\
\hline Glucose (mg/dl) & $<50$ & $<50$ & Ns & - \\
\hline $\mathrm{pH}$ & $5.25 \pm 0.5$ & & Ns & $5.4 \pm 0.7$ \\
\hline
\end{tabular}

When kidney transplant recipients were compared to the normal population there were significant differences between the two groups in creatinine, NAG, AAP, total protein and microalbuminuria. These parameters however were elevated in the transplant recipients (Table 5). 
Table 5. Comparison between control subjects and kidney transplant patients. The means and standard deviations of the studied parameters for normal controls $(n=157)$, and kidney transplant patients $(\mathrm{n}=50), \mathrm{Cr}=$ creatinine.

\begin{tabular}{|l|c|c|c|}
\hline \multirow{2}{*}{ Parameters } & Control subjects & $\begin{array}{c}\text { Kidney transplant } \\
\text { patients }\end{array}$ & \multirow{2}{*}{ P - value } \\
\cline { 2 - 4 } & Mean \pm SD & Mean \pm SD & \\
\hline Creatinine $(\mathrm{mmol} / \mathrm{l})$ & $13.7 \pm 0.5$ & $10.84 \pm 6.11$ & 0.05 \\
\hline NAG $(\mu \mathrm{mol} / \mathrm{h} / \mathrm{mmol}$ creatinine $)$ & $12.46 \pm 0.6$ & $85.4 \pm 74$ & 0.001 \\
\hline AAP $(\mathrm{U} / \mathrm{mmol}$ creatinine $)$ & $1.3 \pm 0.58$ & $2.46 \pm 2.72$ & 0.001 \\
\hline ALP $(\mathrm{U} / \mathrm{mmol}$ creatinine $)$ & $0.34 \pm 0.2$ & $0.84 \pm 0.65$ & 0.05 \\
\hline Total protein $(\mathrm{mg} / \mathrm{mmol}$ creatinine) & $7.01 \pm 0.37$ & $77.81 \pm 147.72$ & 0.025 \\
\hline Microalbuminuria $(\mathrm{mg} / \mathrm{mmol}$ creatinine) & $0.9 \pm 1.8$ & $5.04 \pm 9$ & 0.001 \\
\hline Glucose $(\mathrm{mg} / \mathrm{dl})$ & $<50$ & $<50$ & - \\
\hline $\mathrm{pH}$ & $5.25 \pm 0.01$ & $5.4 \pm 0.70$ & NS \\
\hline
\end{tabular}

\section{The Relationship between Urinary NAG and Microalbuminuria}

Control Subjects: Increased levels of $\mathrm{NAG} / \mathrm{Cr}$ is associated with an increase in microalbuminuria as shown in Fig. 1. As microalbuminuria increases, NAG/ $\mathrm{Cr}(\mathrm{U} / \mathrm{mol} / \mathrm{h} / \mathrm{mmolCr})$ increases, but by only one unit.

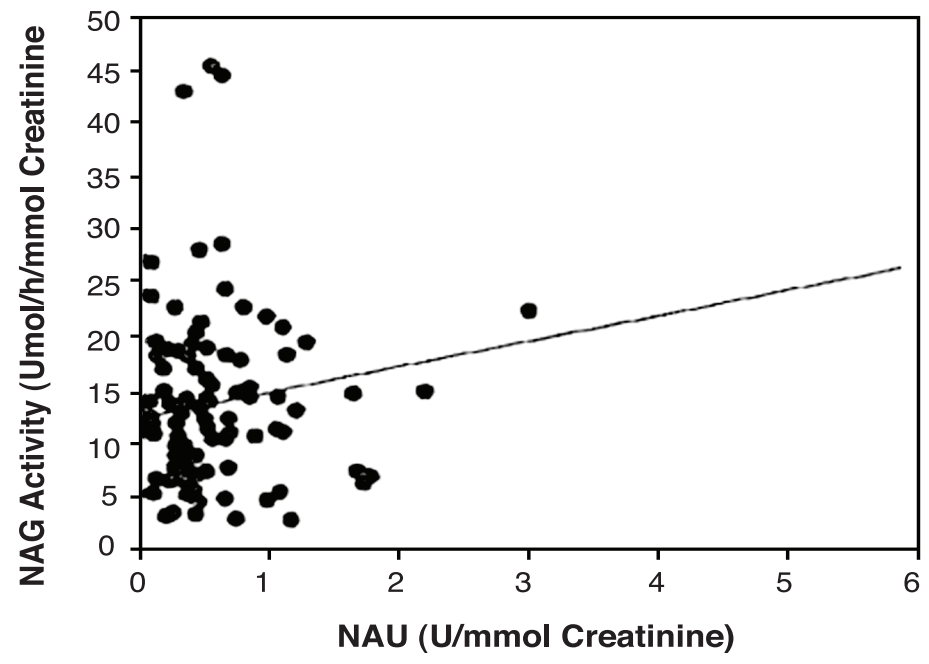

Fig. 1. NAG/Cr and microalbuminuria/Cr in normal subject.

Kidney Patients and Kidney Transplant Recipients: Increased levels of $\mathrm{NAG} / \mathrm{Cr}$ are associated with increased levels of microalbuminuria (Fig. 2 and 3). 


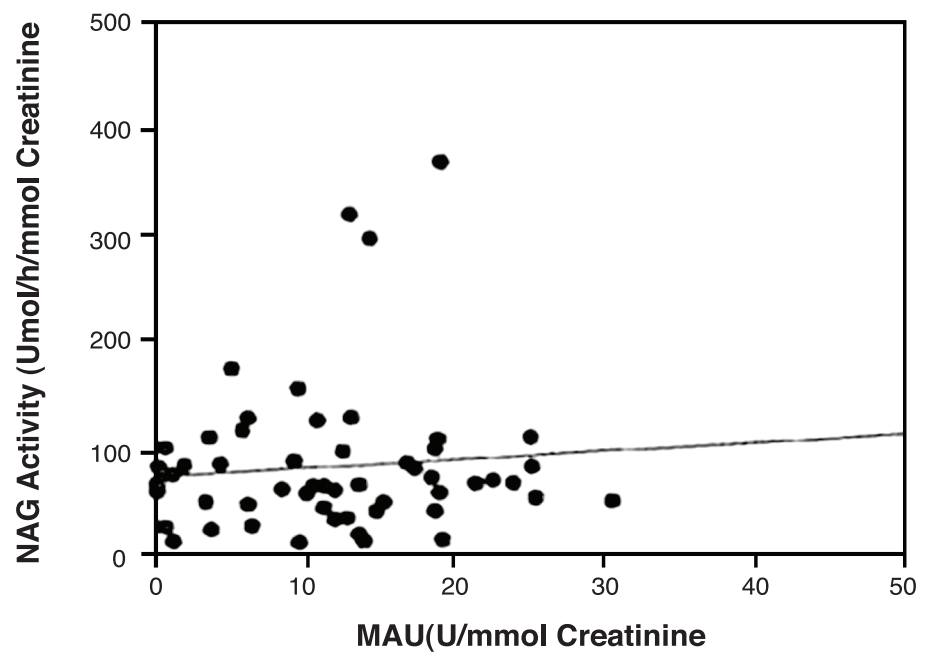

Fig. 2. NAG/Cr and microalbuminuria/Cr in kidney patients.

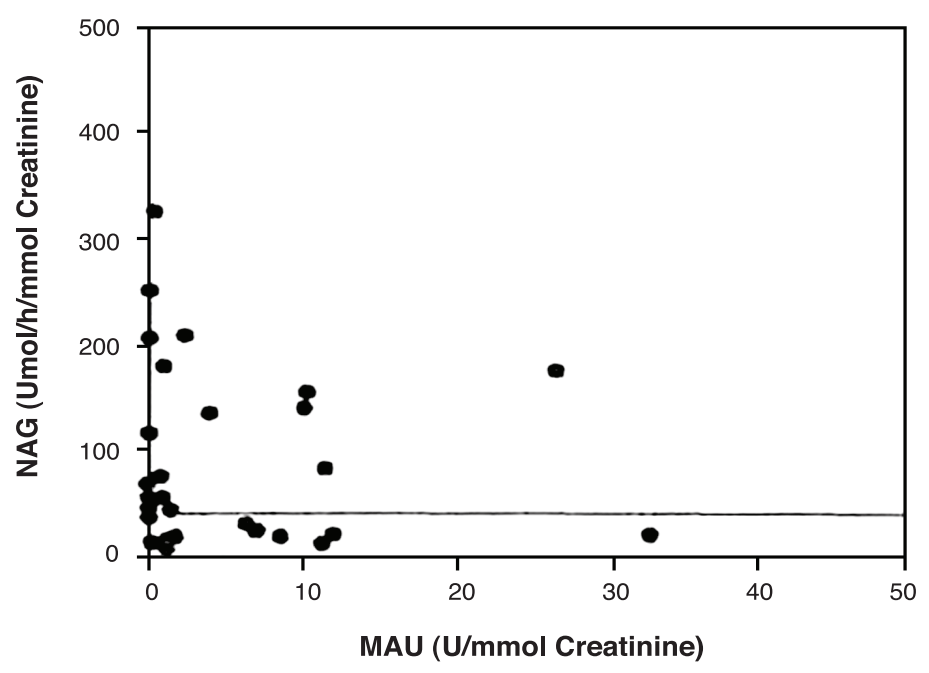

Fig. 3. NAG/Cr and microalbuminuria/Cr in kidney transplant recipients.

\section{Urinary Protein Profile}

SDS-polyacrylamide gel electrophoresis (SDS-PAGE) was performed with urine which was concentrated in a rotary concentrator (1:100).

The urinary protein profile of normal subjects was characterized by one main band at $69 \mathrm{kD}$, corresponding to albumin, with some bands lower than $50 \mathrm{kD}$ (Fig. 4), while the urinary protein profile of kidney patients was characterized by one main band at $69 \mathrm{kD}$, corresponding to albumin. The other smaller bands 
disappeared in some samples (Fig. 5; lanes 4 and 7). Other smaller bands have appeared in some other samples of $69 \mathrm{kD}$ molecular weight, or even smaller sizes (Fig. 5; lanes 3,4,5,6 and 7).

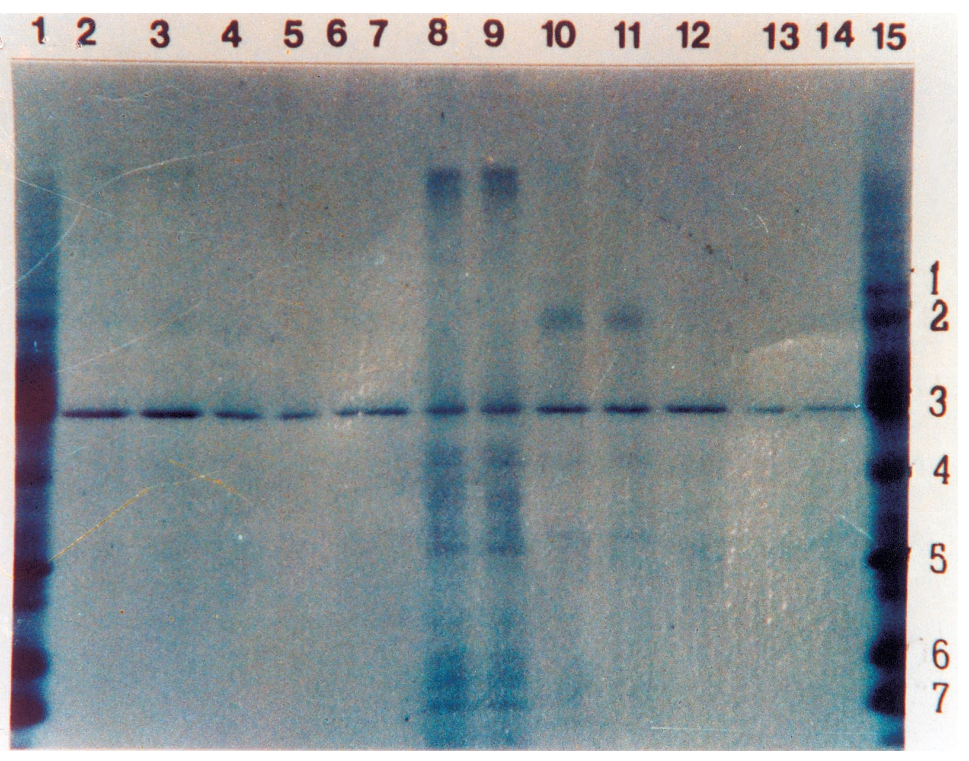

Fig. 4. Urinary protein profile in control subjects. SDS-PAGE was performed with urine from control subjects. Concentrated in rotary concentrator 1:100. Lane 2 to 14: Urine from control subjects. Lane 15: Molecular weight markers where:
$1 .=200 \mathrm{kD}$
5. $=30 \mathrm{kD}$
2. $=92.5 \mathrm{kD}$
6. $=21.5 \mathrm{kD}$
3. $=69 \mathrm{kD}$
7. $=14.3 \mathrm{kD}$
4. $=46 \mathrm{kD}$

\section{Discussion}

\section{Normal Subjects}

In the present study a number of markers for renal nephropathy have been assayed in Saudi controls and patients with different renal diseases. This is the first report for the use of these materials to study renal complication in the Saudi population.

The results obtained for urinary enzyme markers were in close agreement with those found in two studies, Price (1992) ${ }^{[17]}$ and Jung et al. ${ }^{[18]}$. No significant difference were found between males and females in control Saudi subjects. 


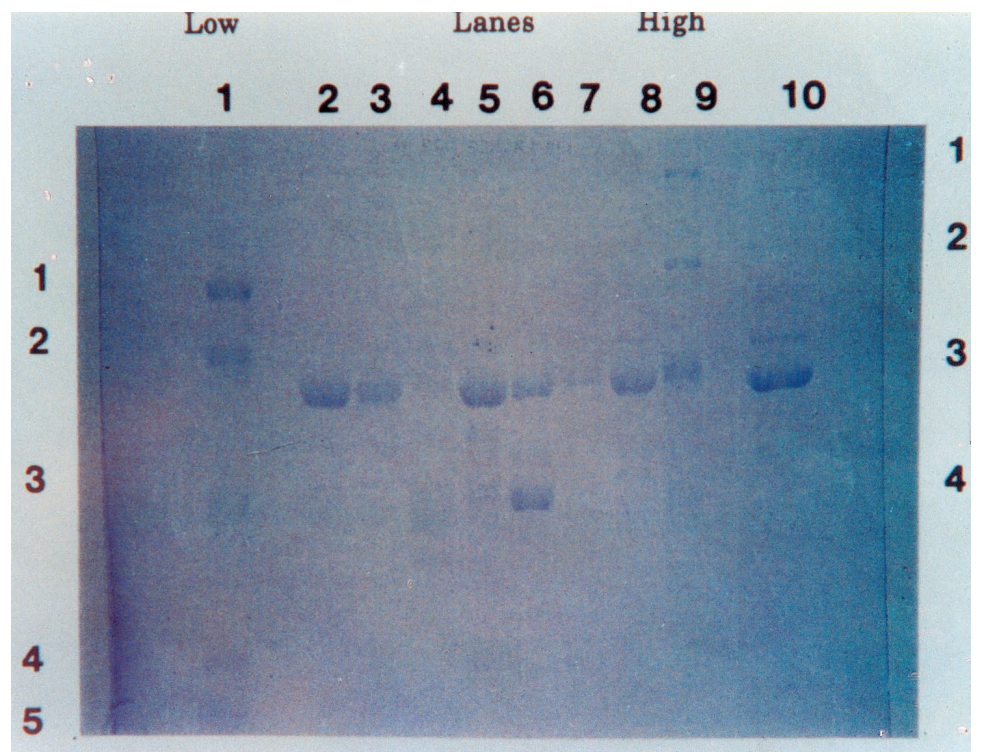

Fig. 5. Urinary protein profile in individual with kidney diseases. SDS-PAGE was performed with urine from individuals with kidney damage. Lane 1: Molecular weight markers (see Fig. 4). Lanes 2, 3, 4, 5, 6, 7, 8 and 10: Urine from individuals with kidney diseases.

\section{Kidney Patients}

There were statistically significant differences in most of the parameters investigated between kidney patients and the normal population, except for glucose level and $\mathrm{pH}$. Glucose results mean that the patients were not diabetics. The reduction in creatinine concentration $(\mathrm{P}>0.001)$ may reflect changes in the glomerular filtration rate (GRF). All patients suffering from renal failure have glomerular filtration rate below $40 \mathrm{ml} / \mathrm{min}$ per $1.73 \mathrm{~cm}^{2[2]}$.

A low glomerular filtration rate is also due to renal circulatory insufficiency, intrinsic renal damage or post renal causes ${ }^{[20]}$. Creatinine may also be partly destroyed by bacterial action in older or infected urine ${ }^{[20]}$. The variability of creatinine is also dependent on age, sex, non-creatinine chromogens, serious analytical interference by bilirubin, acetoacetate and many drugs ${ }^{[20,21]}$.

Creatinine measurements may suggest that these patients are at end stage or renal failure. There were significant differences between the patients and normal subjects concerning NAG, AAP, ALP, total protein and microalbuminuria. 
Higher levels of urinary NAG activity were associated with high microalbuminuria $(\mathrm{P}=0.001)$ and raised urinary AAP levels $(\mathrm{P}=0.001)$, as shown in Table 3 and Fig. 2 and 3.

Increased urinary NAG predominantly reflects tubular damage and is most likely associated with a decrease in functional nephrons. More significant changes were encountered in the total urinary NAG activity with patients with glomerular damage, especially those with severe proteinuria. Raised levels of the brush border enzyme AAP reflects decreased renal function and tubular damage.

An increased level of ALP activity in urine indicates a lesion of the proximal convoluted tubules and/or intensive regeneration of the tubular epithelial cells ${ }^{[2]}$. Intensive regeneration of these cells may also occur in the recovery phase of renal disease and probably accompanies light or medium renal injury. The enzyme is also elevated in glomerulonephritis, pyelonephritis, renal insufficiency, cystic kidney and hypertension ${ }^{[21]}$ and in renal tubular damage ${ }^{[22]}$.

A marked decrease was encountered in total urinary ALP activity obtained for normal controls $(0.34 \pm 0.2 \mathrm{U} / \mathrm{mmol}$ creatinine $)$ compared with the results obtained by ${ }^{[2]}$ who showed that ALP for adults was $1.6 \mathrm{U} / \mathrm{mmol}$ creatinine ${ }^{[23]}$.

The increase in NAG activity correlates well with urinary protein and may indicate an increase in activity of renal tubular cells, especially with a large amount of protein present in the renal tubular lumen ${ }^{[24]}$.

\section{Kidney Transplant Recipients}

The results obtained for kidney transplant recipients showed a significant increase in NAG, ALP and AAP enzymes. As has been demonstrated by Jung and Kotanko ${ }^{[25]}$, the remarkable increase in most parameters may indicate that patients are in an immediate functioning graft. Graft function and morphological integrity may be influenced by pre-transplant variables, including the donor's condition such as blood pressure and underlining diseases for living donor or cadaveric grafting. In addition to the pre-transplant graft damage and the intraoperative alterations, other factors like rejection or infection may alter the post-transplant enzymuria. Pathological reasons for the increase of postoperative enzyme excretion are: Release of enzymes from the damaged and not fully functioning kidney cells, disturbed glomerular filtration barrier and insufficient reabsorptive-catabolizing function of the tubular cells.

The elevated enzyme excretions are derived from the kidney and plasma. Intracellular enzymes such as AAP and NAG are released, and brush border membrane with enzymatic properties is shed with the urine ${ }^{[26,27]}$. The enzymes are then washed out by the revived diuresis and appear in the urine. 
It has been documented by many investigators that there is a significant correlation between AAP excretion and decreased renal function. Increased urinary ALP activity was found after kidney transplantation ${ }^{[2]}$. ALP is also elevated during a kidney rejection crisis after transplantation ${ }^{[21]}$, treatment with gentamycin and as a consequence induction of the synthesis of the enzyme as a result of toxic or inflammatory lesion of the kidney, and not only as a result of the loss of enzyme from the damaged cells ${ }^{[2]}$.

In addition, raised microalbuminuria found in kidney transplant recipients results from the disturbed glomerular filtration barrier as a result of nonsensitive proteinuria, leading to the appearance of serum enzymes in the urine. Serum AAP isoenzyme, as well as NAG and ALP, are found in the urine when proteinuria exceeds $1 \mathrm{~g} /$ day $^{[28,29]}$.

In the current work, raised protein levels $(\mathrm{P}=0.025)$ as well as microalbuminuria $(\mathrm{P}=0.001)$ have been demonstrated. Glucose remained $<50 \mathrm{mg} / \mathrm{dl}$, which shows no indication of hyperglycemia. No significant difference was recorded for urinary $\mathrm{pH}$. However, these patients have an uncomplicated postoperative course. Higher urinary enzyme activity than in controls indicates a healthy uncomplicated transplantation.

A significantly high relationship was shown for $\mathrm{NAG} / \mathrm{Cr}$ and microalbuminuria/Cr for normal subject, kidney patients and kidney transplant recipients (Fig. 1, 2 and 3).

\section{Urinary Enzyme Profile}

When urine protein was fractionated on gel electrophoresis. The urine of control subjects showed one main band at $69 \mathrm{kD}$ corresponding to low molecular weight protein.

Urinary protein of kidney patients was also characterized by one main band (albumin), although it disappears in some samples. The smaller bands appearing in some samples $(69-50 \mathrm{kD})$ may correspond to low molecular weight protein which could be enzyme released in urine as a result of tubular damage or protein degradation.

The low intensity of the smaller bands suggests low concentrations of total protein of the high molecular weight one ${ }^{[30]}$.

In conclusion, the decrease of creatinine concentration in kidney patients does not account for the elevation in other parameters. The elevation is probably due to the dysfunction of their kidneys, which may be damaged. 
Parameters investigated for kidney transplants indicate that they are in uncomplicated stage.

Investigated parameters, such as NAG, ALP, AAP, microalbuminuria and others were valid for this study, they may not be useful in diagnosis at a late stage of kidney failure, but they might be useful in monitoring the progress of the disease, and studying the effect of the treatment of established renal failure. However, these parameters may be suggested as useful markers for early detection of kidney diseases and transplantation in the Saudi population. The NAG assay, together with the brush border enzymes and microalbuminuria, may be used as an alternative measurement for renal dysfunction.

Several studies have been carried out on hypertension and kidney damage. Such as studies carried out on normotensive and hypertensive renal transplant recipients with high level of microalbuminuria ${ }^{[31]}$ and on tubular injury and the first symptom of hypertensive kidney involvement ${ }^{[32]}$ and markers of renal damage in recently diagnosed hypertensive patient ${ }^{[33]}$.

\section{References}

[1] Boyd, P.N., Halman, J., Taylor, S.A. and Price, R.G., Enzyme release in nephrotoxicity and renal disease, Cells, Membranes and Disease including Renal, Eds.: Eric Reid, G.M.W. Cock and J.P. Luzio, Plenum Publishing Corporation, 2: 409-416 (1987).

[2] Jung, K., Mattenheimer, H. and Burchardt, U., Urinary Enzymes in Clinical and Experimental Medicine, London: Springer-Verlag (1992).

[3] Price, R.G. and Whiting, P.H., Urinary enzymes and nephrotoxicity in humans. In Urinary Enzymes in Clinical and Experimental Medicine, Eds.: Jung, Mattenheimer and Burchardt, Pub. Springer-Verlag, Berlin, 203-216 (1992).

[4] Fukanawa, S., Itoh, T., Miyata, K., Tochino, Y. and Nakamura, M., Sex difference of Nacetyl- $\beta$-D-hexosaminidase activity in the kidney, urine and plasma of mice, Renal Physiol. Basel., 7: 124-128 (1984).

[5] Rebel, W.T., Bertsh, B.G. and Bleuel, H., Enzymuria as in an indicator of renal pathomorphology. In: Urinary Enzymes in Clinical and Experimental Medicine, Eds: Jung, Mattenheimer and Burchardt, Pub. Springer-Verlag, Berlin, 43-66 (1992).

[6] Yuen, C.T., Kind, P.R., Price, R.G., Praill, P.F.G. and Richardson, A.C., Colorimetric assay for $\mathrm{N}$-acetyl- $\beta$-D-glucosaminidase (NAG) in pathological urine using the $\omega$-nitrostyryl substrate; the development of a kit and the comparison of manual procedure with the automated fluorimetric method, Ann. Clin. Biochem., 21: 295-300 (1984).

[7] Price, R.G., Urinary enzyme nephrotoxicity and renal disease, Toxicology, 23: 99-134 (1982).

[8] Viberti, G.C. and Keen, H., The patterns of proteinuria in diabetes mellitus, relevance to pathogenesis and prevention of diabetic nephropathy, Diabetes, 33: 686-692 (1984).

[9] Viberti, G.C. and Wiseman, M.J., The kidney in diabetes, significance of the early abnormalities, Clin. Endocrinol. Metab., 15: 783-806 (1986).

[10] Viberti, G.C., Keen, H. and Wiseman, M.J., Raised arterial pressure in patients of proteinuria insulin-dependent diabetics, Brit. Med. J., 296-515 (1987). 
[11] Vittinghus, E. and Mogenset, C.E., Graded exercise and protein excretion in diabetic man and the effect of insulin treatment, Kidney Int., 21: 725-729 (1982).

[12] Bonsnes, R.W. and Taussky, H.H., The colorimetric determination of creatinine by the Jaffe' procedure, J. Biol. Chem., 158: 581-591 (1945).

[13] Jaffe', M., The colorimetric determination of creatinine by the Jaffe' procedure, J. Biol. Chem., 158: 581-591 (1886).

[14] Wellwood, J.M., Ellis, B.G., Price, R.G. and Thompson, A.F., Urinary N-acetyl- $\beta$-Dglucosaminidase activities in patients with renal disease, Brit. Med. J., 3: 408-411 (1975).

[15] Mattenheimer, H. and Jung, K., Grlsch., Methods for measuring urinary enzyme activities. In: Jung, Mattenheimer and Burchardt (eds), Urinary Enzymes in Clinical and Experimental Medicine, Berlin: Springer-Verlag, 99-109 (1992).

[16] Bradford, M.M., A rapid and sensitive method for the quantitation of microgram quantities of protein utilizing the principle of protein dye binding, Anal. Biochem., 72: 248-254 (1979).

[17] Price, R.G., The role of NAG (N-acetyl- $\beta$-glucosaminidase) in the diagnosis of kidney disease including the monitoring of nephrotoxicity, Clin. Nephrol., 38: 1514-S 19 (1992).

[18] Jung, K., Hempel, A., Grulzmamm, K.D., Hempel, R.D. and Schneiken, G., Age dependent excretion of alanine aminopeptidase, al;aline phosphatase. T-glutamyl transferase and $\mathrm{N}$-acetyl- $\beta$-D-glucosaminidase in human urine, Enzyme, 43: 10-16 (1990).

[19] Alzaid, A.A., Microalbuminuria in patients with NIDDM; An overview, Diabetes Care, 19: 79-89 (1996).

[20] Zilva, J.F., Pannal, P.R. and Mayne, P.D.A., The Kidneys: Renal Calculi. Clinical Chemistry in Diagnosis and Treatment, Lloyd-Luke, London. 1-24 (1987).

[21] Pfleiderer, G., Mossner, E. and Baier, M., Kaufmann, T., Role of Alkaline Phosphatase Isoenzyme Determination in Urine for Non-Invasive Diagnosis of Kidney Disease, Ed Gert Lubec. Pub. Karger Vienna, S: 53-72 (1983).

[22] Shlbasaki, H., Ishimoto, G. and Miyahars, T., Urinary N-acetyl- $\beta$-D-glucosaminidase isoenzyme activity as measured by fast protein liquid chromatography in patients with nephritic syndrome, Clin. Chem., 36 (1): 102-103 (1990).

[23] Moss, D., The scientific foundation of clinical enzymology, Naturwesenschaflen, 64: 253259 (1977).

[24] Kind, P., Patterns of N-acetyl- $\beta$-D-glucosaminidase isoenzyme activity in human physiology and pathological situations. PhD Thesis, Faculty of Medicine for the Degree of Doctor of Philosophy, University of London (1983).

[25] Jung, K. and Kotanko, P., Urinary enzymes in kidney transplantation. In Urinary Enzymes in Clinical and Experimental Medicine, Eds: K. Jung, H. Mattenheimer and Burchardt, Pub. Springer-Verlag, Berlin, SS: 189-199 (1992).

[26] Koivula, T., Pitkanen, E., Tutro, H. and T ssterman, T., The excretion of urinary nacetyl- $\beta$-D-glucosominidase and $\beta$-glucoronidase as a sign of impending rejection of kidney transplants, Ann. Clin. Res., 10: 288-290 (1978).

[27] Jung, K., Pergande, M., Reinholdt, C., Schulze, B. and Stro belt, V., Multiple form of alanine aminopeptidase, alkaline phosphatase and gamma-glutamyl transferase in urine of healthy persons patients suffering from kidney disease and patients with kidney transplants, J. Clin. Chem. Clin. Biochem., 22: 523-525 (1984).

[28] Butterworth, P.J., Moss, D.W., Pilkanen, E. and Pringle, A., Some characteristics of alkaline phosphatase in human urine, Clin. Chem. Acta., 11: 220-226 (1965).

[29] Price, R.G., Urinary N-acetyl- $\beta$-D-glucosaminidase (NAG) as an indicator of renal disease, Curr. Probl. Clin. Biochem., 9: 150-163 (1979). 
[30] Arce-Tomas, M., Renal changes induced by exposure to heavy metals, London University PhD Thesis (1993).

[31] Satoh, S., Horikawa, Y., Kakinuma, H., Tsuchiya, N., Wang, L., Kato, T. and Habuchic, T., Clinical characters of normotensive renal transplant recipient with microalbuminuria and effects of angiotensin II type 1 receptor antagonist on urinary albumin excretion, Int. J. Urol., 11 (80): 585-591 (2004).

[32] Tylicki, L., Martin, J., Lysiak-szydlowska, W. and Rutkowski, B., Tubular injury: The first symptoms of hypertensive kidney involvement? Med. Sci. Morit., 9 (4): CR 135-141 (2003).

[33] Maldonado-Martin, A., Rueda-Illescas, D., Gil-Extremera, B., Soriano-Carrascosa, L., Alonso-Morales, T., Garcia-Perez, F., Garcia-Chicano, J. and de Dios Luna del Castillo, J., Endothelins and markers of renal damage in recent diagnosed hypertensive patients, $J$. Clin. Hypertens. (Greenwich), 4 (5): 346-g-354 (2002). 


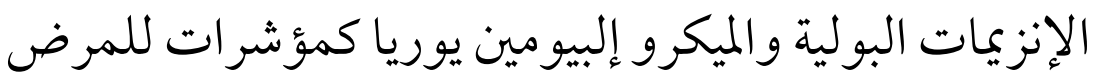 الكلوي في المرضى السعوديين
}

\author{
سهيره أحمد لاري \\ قسم الكيمياء الحيوية، كلية العلوم، جامعة الملك عبد العزيز لمبري

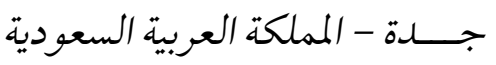

المستخلص. تم في هذا البحث دراسة بعض المؤشرات الإنزيمية الحيوية

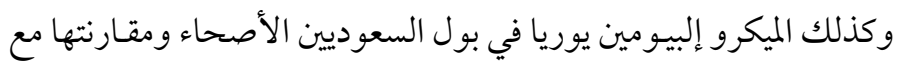
مرض الكلية و مرض زراعة الكلية في كل من الذكور والإناث.

والمؤشـرات التي تم تقــيرهـا هي: إنزيم N-acetyl glucosamindase

Alanine amino- Alkaline phosphatase (ALP) و وإنزيم (NAG)

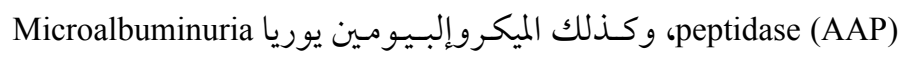

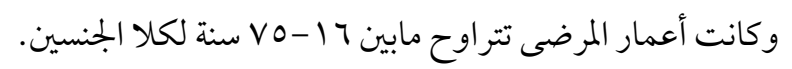

أظهرت النتائج التي تم الحصول عليها ارتفاع نسبة إنزيم (NAG)

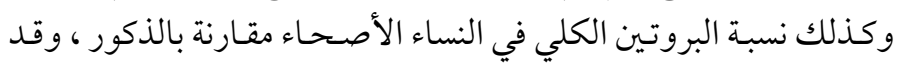

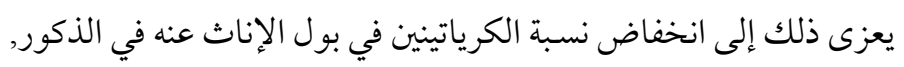

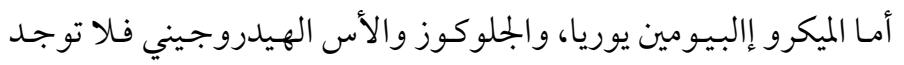

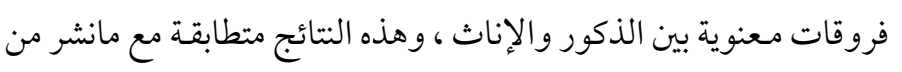
أبحاث في هذا المجال في مختلف أنحاء العالم.

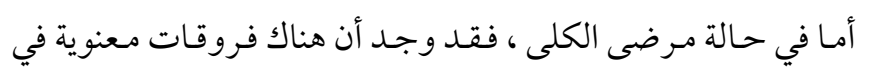

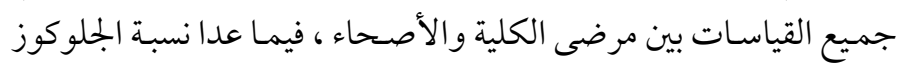

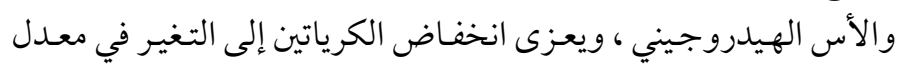
Glomerular Filteration (GFR)

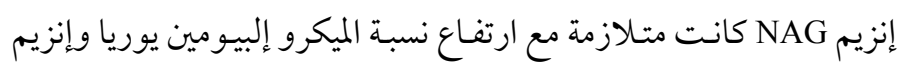

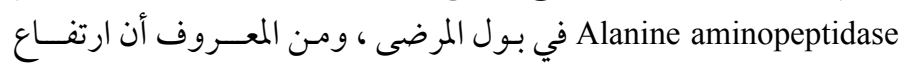
نسبـة إنزيم NAG دلالة على وجــود تلف كلوي في منطقة 
Urinary Enzymes and Microalbuminuria as Indicators of...

161

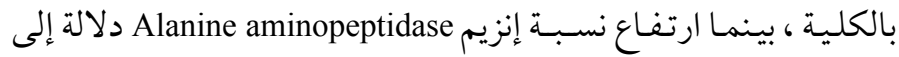

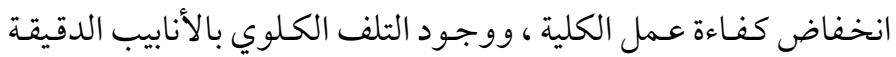
(الأنيبيات) (الموجودة دubular Alkaline phosphatase Proximal convoluted tubules لخلايا الأبيثيليل Epithelial cells للأنابيب داخل الكلى .

وقد لوحظ أن زيادة إنزيم (NAG) تتناسب مع زيادة بروتين الكلى في

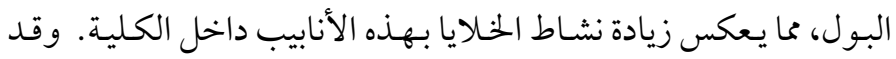

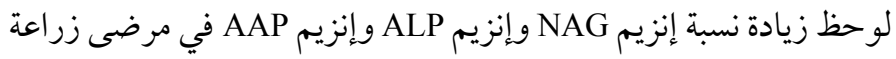

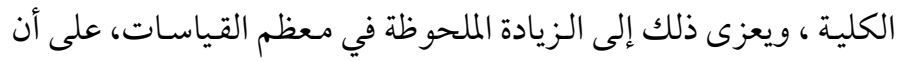

الكلية المزروعة قد بدأت مباشرة عملها الطبيعي.

و وعليه فإن تقدير هذه القياسات تعطي فكرة جيدة عن حالة الكلية

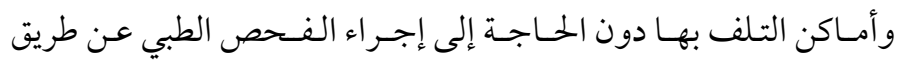

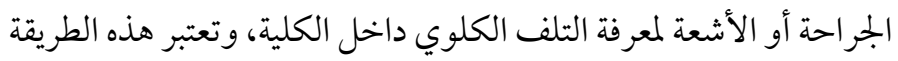

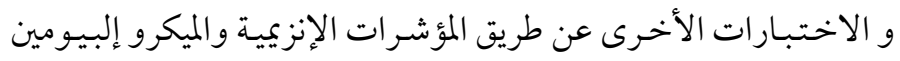

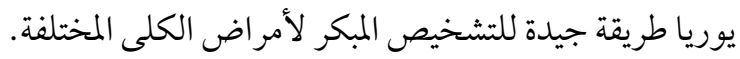

